sufficiently account for the loss of the tubules in these fishes. Obviously much remains to be done before the full significance of the structure of bone can be elucidated, and this paper has been written with the object of drawing attention to the interest and importance of this new line of research.

\title{
List of References.
}

1. Goonrich, E. S.- "On the Scales of Fish, Living and Extinct, and their Importance in Classification." Proc. Zool. Soc. 1908.

2. Goodrich, E. S.- "Vertebrata Craniata" first fascicleCyclostomes and Fishes. Part 9 of 'Treatise on Zoology,' ed. by Sir Ray Lankester. London, 1909.

3. Her'wig, O.- “Ueber das Hautskelet der Fische." Morph. Jahrb. vol. v., 1879.

4. Nickerson, W. S.- "Development of the Scales of Lepidosteus." Bull. Mus. Comp. Zool. vol. xxiv., 1893.

5. Reissner, E.- "Ueber d. Schuppen von Polypterus u. Lepidosteus." Arch. f. Anat. u. Phys., 1859.

6. Stewart, C._- Endoskeleton," in Catal. Roy. Coll. of Surgeons, 2nd edit. vol. i., 1900.

7. Woodward, A. S.-Catalogue of the Fossil Fishes in the British Museum, 4 vols., London, 1889-1901; and 'Outlines of Vertebrate Palæontology,' Cambridge, 1898.

7. Report on the Myzostomida collected by Mr. Cyril Crossland in the Red Sea in 1905. By Charles L. Boulenger, M.A., D.Sc., F.Z.S., Lecturer on Zoology in the University of Birmingham.

[Received November 12, 1912 : Read November 26, 1912.]

(Plates V.-VIII, and Text-figures 17-23.)

INDEX.

\begin{tabular}{|c|c|}
\hline \\
\hline Anatomy of Myzostoma spp. & 88 \\
\hline The "Suckers" of M. costatum F. S. L.. & 90 \\
\hline Ophiurid as the host of $M$. costatum F. S. L. & 88 \\
\hline Abnormalities in M. costatem F.S. L. ......... & 93 \\
\hline M. costatum F. S. L. ........ & 87 \\
\hline M. rubrofasciatum v. Graff & 101 \\
\hline M. crosslandi, sp. n. ......... & 102 \\
\hline List of References & 107 \\
\hline xplanation of the Plates & 10 \\
\hline
\end{tabular}

The Myzostomida described in this report were collected by Mr. Cyril Crossland on the Sudanese coast of the Red Sea in 
1905 and were sent, together with the other Annelida, to Mr. F. Potts, of Trinity Hall, Cambridge, who submitted them to me for examination.

$\mathrm{Mr}$. Crossland's collection is of considerable interest, since very little is known of the Red Sea Myzostomida, and the only two species recorded from that locality were described from very scanty material.

The material as I received it from Mr. Potts consisted of six tubes containing about 170 specimens. Of these six belong to a species hitherto unknown and which I take great pleasure in dedicating to Mr. Crossland; two I have referred to v. Graff's Myzostoma rubrofasciatum, described from a single specimen in 1884; whilst the remainder belong to a species which I take to be the old-established form Myzostoma costatum, one of the first three species of the group described by Leuckart so long ago as 1830 .

The importance of a collection of this kind, however, is not to be judged by the number of species represented in it. About 100 species of Myzostoma are on record and of these by far the greater number have been described from external characters only, ill-preserved or limited material having made a complete examination impossible. Mr. Crossland's specimens were in an excellent state of preservation and I have been able to give a fairly complete account of the anatomy of two of the forms mentioned above; moreover, the very large series of specimens of M. costatum reveals a range of variation remarkable even for this group of animals, and affords an opportunity of judging the merits of various characters for systematic purposes.

In my descriptions of the species I have endearoured to give as complete an account as possible of the general morphology of the various organs, especially of those which might be of taxonomic interest. I have, however, refrained from attempting any histological decriptions, as I felt it useless to do so without material specially preserved for such a purpose. Throughout this paper I have retained as far as possible the nomenclature of parts used by v. Graff $(\mathbf{7}-9)$ * and Nansen (15), and have not followed the example set by some of the more recent workers on the Myzostomida.

I desire to take this opportunity of thanking Mr. Potts for entrusting me with this valuable material; Prof. F. Jeffrey Bell very kindly allowed me to examine some of the types of the 'Challenger' collection of Myzostomida preserved in the British Museum (Natural History), and I am also indebted to Mr. H. C. Chadwick, of the Port Erin Biological Station, for information concerning the Red Sea Echinoderms from which Mr. Crossland's specimens were obtained $\uparrow$.

* The figures in brackets refer to the List of References on p. 107.

+ I also wish to express my indebtedness to Mr. Cox, of the Zoological Department of this University, for the excellent photographs reproduced on PI. VIII. 
Myzostoma costatum F. S. Leuckart. (Pl. V.\& Pl. VIII. figs. 2-4.)

M. costatum Leuckart (10), p. 612 ; (11), p. 8, pls. i.-ii.

$$
\text { " v. Graff (7), p. 11, pl. i. figs. 13-14; (8), p. } 32 .
$$

Myzostoma costatum was one of the first three species of the genus described by F. S. Leuckart in $1830(10)$, his account being based on specimens obtained in the Red Sea from Comatula multiradiata Lam.

A more complete description of these specimens was published by the same author in 1842 (11), together with the following brief diagnosis of the species:-

"Char. specif.: Corpore depresso, ovali, margine crenulato, dorso costato; acetabulis suctoriis et hamuliferis separatis, acetabulis utrinque quatuor et hamulis in utroque latere quinque. Hab. in mari rubro, Comatulæ multiradiatæ parasitus."

The species was rediscovered by Semper, who obtained two specimens from Bohol, in the Philippines, and these were described by v. Graff in his well-known monograph published in $1877(7)$. The two individuals, which measured $3 \frac{1}{2}$ and $2 \frac{1}{2} \mathrm{~mm}$. in length respectively, agreed closely with those described by Leuckart. The dorsal surface presented the characteristic riblike elevations which gave the name to the species, and, moreover, the animals possessed another feature noticed by Leuckart, namely a small triangular incision at the anterior end of the body, at the apex of which the mouth is situated. v. Graff's diagnosis of $M$. costatum was as follows:- "Corpus ovale depressum, incisura antica triangulari, griseo- aut nigro-brunneum, supra costatum. Costa una longitudinalis mediana qua communicantes 10-14 costæ transversales ad marginem productæ. Margine orientes inter has costæ breviores secundariæ et tertiaræ illam longitudinalem non attingentes marginemque crenulantes. Parapodia crassitudine uncinorumque forma M. glabrum, longitudine M.cirriferum æquantia. Acetabula elliptica. Os ad basin incisuræ triangularis, ventrale, papilla cloacalis ventralis. Longit. ad $3 \frac{1}{2} \mathrm{~mm}$. In mari rubro Comatulæ multiradiatæ Lam., in mari prope Bohol Actinometra solaris Lam. incola."

A few years later v. Graff obtained another specimen, collected by Haeckel at Tur, near Sinai, and described it in the 'Challenger' Expedition Report (8). This specimen was of a yellowish-brown colour and measured nearly $2 \mathrm{~mm}$. in length. The breadth was rather greater than the length, and the anterior notch, as well as the "ribs," were not so distinct as in the specimens from Bohol; the marginal notches were, however, more marked.

As mentioned above, of the large number of Myzostomids collected by Mr. Crossland more than 160 belong to a species which, although differing somewhat from previous descriptions, I have decided to refer to Leuckart's $M$. costatum. The series of specimens is a most interesting one, containing individuals of all sizes between 0.5 and $4 \mathrm{~mm}$. in length and presenting a wide range of variation.

Mr. Crossland's specimens were obtained from two localities: 
(a) at a depth of 10 fathoms in Suez Bay on Antedon serripinna Carpenter, (b) at Ul Shubuk (9 fathoms) from Antedon savignyi Müller, and from Ophiurids * which lived with their arms twisted round those of the Crinoid. This is not the first time an Ophiurid has been described as the host of Myzostomids: H. L. Clark in 1902 (4) called attention to the occurrence of a species $\uparrow$ on Asteroceras pergamena Lyman, and remarked that the position of the worms upon the concave underside of the arms made it clear that they had not become accidentally attached to the Ophiurids since the latter were dredged $\ddagger$. With regard to Mr. Crossland's specimens, I think there can be little doubt but that the actively moving Myzostomids had migrated from the arms of the Antedon on to those of the commensal Ophiurids; it is important to note that Antedon savignyi is most probably the Comatula multiradiata Lam., from which Leuckart obtained his type-specimens of Myzostoma costatum.

A typical adult individual ( $c f$. Pl. V. figs. 1-5) has a flat body, approximately oval in shape; the breadth is usually greatest anteriorly, the posterior region narrowing slightly behind the last pair of parapodia. There is no distinct transparent border, the intestinal and uterine branches extending to the bodymargin.

On the dorsal surface a median longitudinal elevation is well marked, running along the whole length of the animal; it is broadest near the middle of its course. From this median elevation arise 6-8 (usually 7 ) pairs of primary costæ which radiate outwards and terminate on the body-margin. The second to fifth pairs are frequently the most developed, the first and last two or three being less distinct and often incomplete. Between the primary costæ are secondary and tertiary ones, as described by v. Graff, their number and arrangement varying greatly. In some individuals the costæ are broken up so as to form rows of flat tubercles (Pl. V. fig. 2). The body is thickest in the region of the median longitudinal elevation and gradually thins down towards the margins.

According to Mr. Crossland's notes, the colour of the living worms is "greenish white, with white dorsal ridge and two longitudinal grey lines on either side of it." The colour of the preserved specimens varies considerably; a few individuals kept in a separate tube are of a greenish-grey colour, but the majority are of a dark sepia-brown; this coloration is probably artificial and due to some dissolved pigment in the alcohol with which the worms were preserved.

The margin of the body is indented so as to form a series of broad, approximately triangular processes, of which in a well-

* Not yet identified.

t This species has since (1906) been described by McClendon (13) under the name of Myzostoma japonicum.

\# Another species of Myzostoma has since been recorded from Ophiacantha vivipara (Koehler, Bull. Sc. France et Belg. vol. xli. p. 279), cf. also Fedotov (6). 
developed specimen there are 40-50, roughly corresponding to the number of costæ which terminate on them. These processes are, of course, cirri ; they are better developed and more regular in size in some individuals than in others, but in most cases they present the appearance of typical cirri only on the anterior margin in front of the mouth, where the body is thinner and more delicate than posteriorly. The last pair of cirri is in most cases considerably enlarged, forming a pair of caudal apperdages into which

Text-fig. 17.

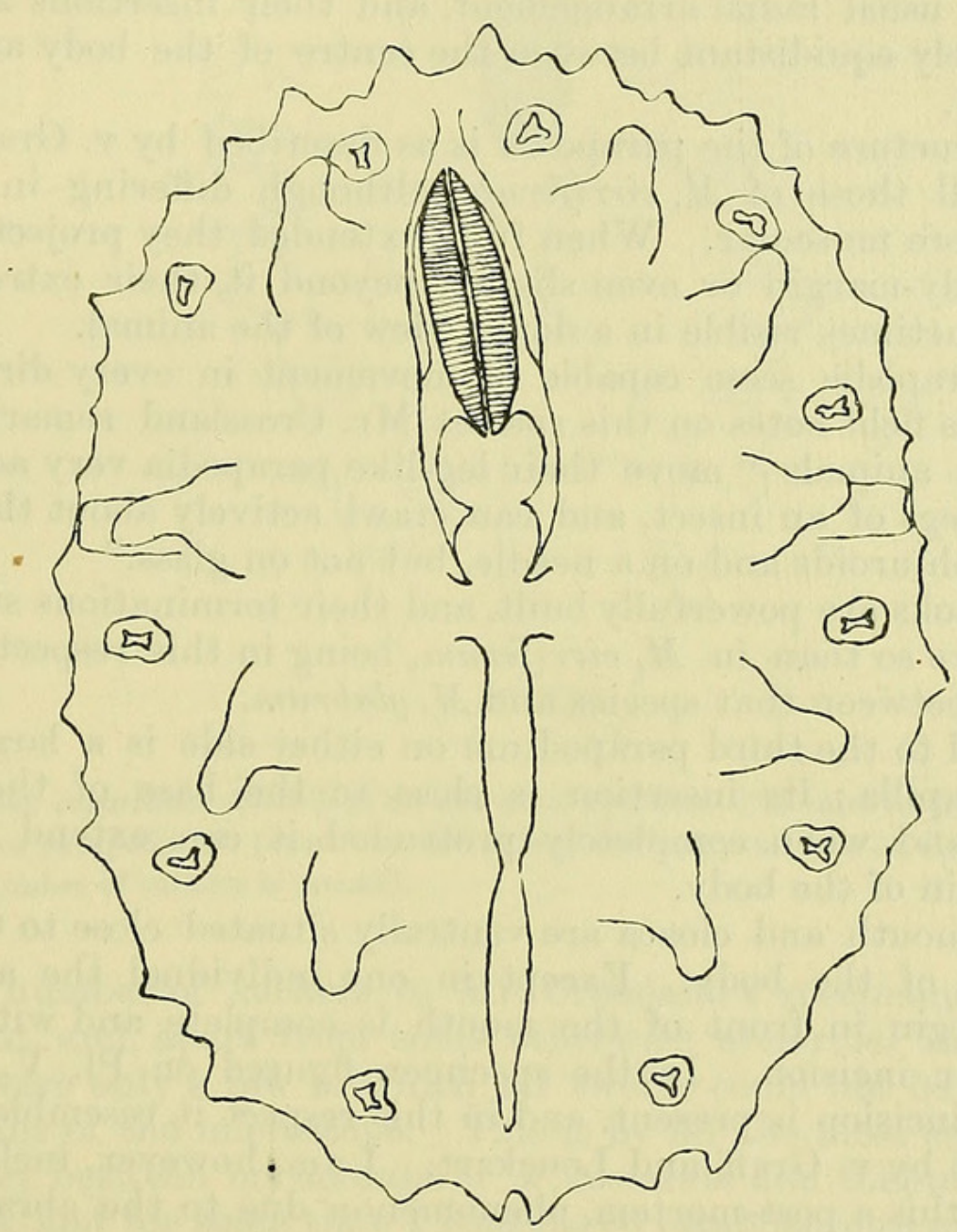

Myzostoma costatum.-Sketch of a mounted specimen $225 \mathrm{~mm}$. in length. Caudal appendages are not present and the individual is abnormal in possessing only four parapodia and five suckers on one side of the body.

branches of the alimentary canal and uterus extend; in some individuals these appendages reach a length equal to nearly onesixth of the length of the body. The penultimate and antepenultimate pairs of processes are frequently enlarged also, but never quite to the same degree.* The shape of the posterior extremity

* This characteristic enlargement of the posterior cirri was not described by previous investigators of this species ; v. Graff's figure (7, pl. i. fig. 14a), however, shows a distinct triangular incision at the posterior end of the body, indicating that something of the kind occurred in the specimens examined by him. 
of the body is subject to great variation, and it seems that the development of caudal appendages bears no relation to the size of the individual, these organs being absent in some specimens of considerable size ( $c f$. text-fig. 17), and, per contra, being well developed in individuals under a millimetre in length.

The presence of caudal processes, as well as the number of these organs, are characters which have been used to a considerable extent for taxonomic purposes; the above description, however, shows how unsafe it is to fix the limits of species by them.

The ventral surface is quite smooth; the five pairs of parapodia have the usual radial arrangement, and their insertions are approximately equidistant between the centre of the body and the periphery.

The structure of the parapodia is as described by v. Graff (7); they recall those of $M$. cirriferum, although differing in being rather more muscular. When fully extended they project as far as the body-margin or even slightly beyond it, their extremities being sometimes visible in a dorsal view of the animal.

The parapodia seem capable of movement in every direction, and in his field-notes on this species Mr. Crossland remarks that the little animals " move their leg-like parapodia very actively, like the legs of an insect, and can crawl actively about the arms of the Ophiuroids and on a needle, but not on glass."

The hooks are powerfully built, and their terminations strongly bent, more so than in $M$. cirriferum, being in this respect intermediate between that species and M. glabrum.

Lateral to the third parapodium on either side is a large male genital papilla; its insertion is close to the base of the parapodium, and when completely protruded it can extend beyond the margin of the body.

Both mouth and cloaca are ventrally situated close to the extremities of the body. Except in one individual the anterior body-margin in front of the mouth is complete and without a triangular incision. In the specimen figured on Pl. V. fig. 4, such an incision is present. and in this respect it resembles those described by v. Graff and Leuckart. I am, however, inclined to consider this a post-mortem phenomenon due to the abrasion of the delicate area which I mentioned above as occurring just in front of the mouth.

In a ventral view of $M$. costatum the "suckers" are quite conspicuous, and of these there are usually six pairs, all equally developed and situater close to the periphery of the body. Four pairs are in the usual position, that is to say in the interspaces between the five pairs of parapodia, these are the second to fifth pairs ; the first is situated in front of the first pair of parapodia, close to the anterior margin, whilst the last or sixth pair of suckers lies approximately halfway between the last pair of parapodia and the posterior median termination of the body.

The suckers have much the same structure as those described by Wheeler (17) in M. glabrum, and when retracted appear as 
spherical or oval bodies with walls so thick that the cavity is almost obliterated or reduced to an irregular ramifying slit between the folds of the wall.

Text-fig. 18.

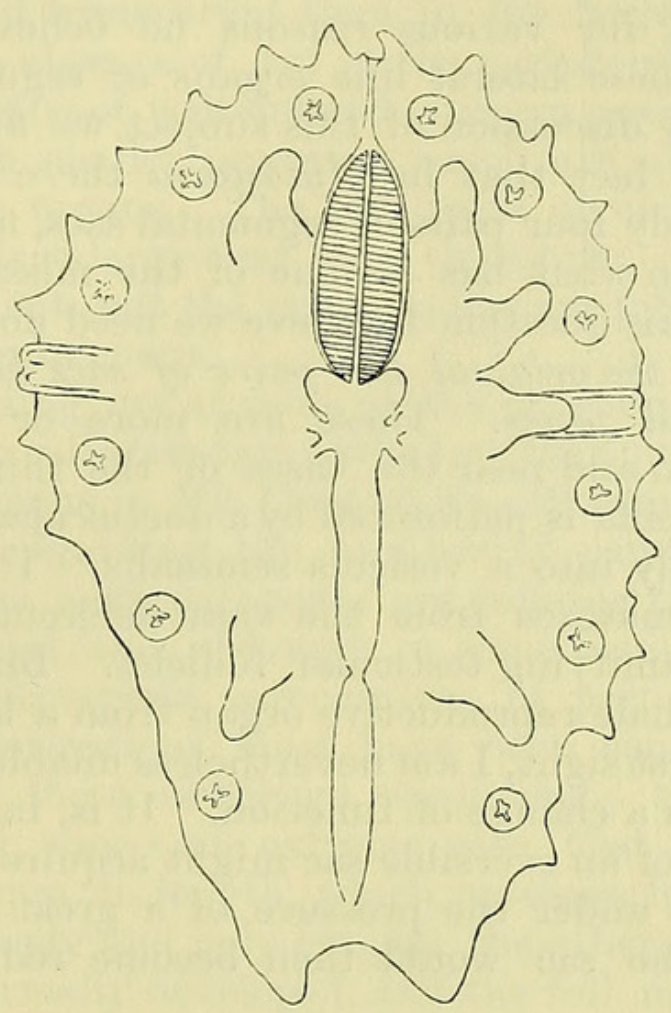

Myzostoma costatum.-Sketch of an abnormal specimen $1.25 \mathrm{~mm}$. in length. Only two parapodia are present on one side of the body, and four on the other; the number of suckers is normal.

The number of suckers in Mr. Crossland's specimens is quite constant, and, apart from some otherwise abnormal individuals, there were only a few in which all twelve could not be made out by means of the microscope. This is by far the most serious discrepancy between my account of $M$. costatum and that of previous authors, and for some time I considered establishing a new species to receive Mr. Crossland's specimens. It seems probable, however, that the extra pairs of suckers have been overlooked; even when well developed these organs are difficult to make out on unmounted specimens of Myzostomids, a fact which the majority of workers on this group have commented on from time to time. Leuckart's description of $M$. costatum was naturally incomplete, and the few specimens seen by v. Graff seem to have been in a rather poor state of preservation and much contracted; no mounts were made, and under the circumstances the extra suckers, if present, might easily have remained unnoticed.

The presence of six pairs of suckers in a species of Myzostoma appears of considerable interest, since it necessitates some modification in the definition of the group, as well as of the generally 
accepted views on the morphology of the Myzostomida. W. M. Wheeler, in his important paper on the sexual phases of these animals (17), discusses the structure and homologies of the suckers at some length. These organs (which he prefers to call segmental sacs) he considers to be metameric, lying laterally or dorsally to their respective parapodia, like the "Seitenorgane" of the Capitellidæ, and for various reasons he believes them to be homologues of these lateral line organs or segmental sacs. In the course of his discussion of this subject we find the following passage :- "The fact that in Myzostoma there are five pairs of parapodia but only four pairs of segmental sacs, naturally leads to the question as to what has become of the missing pair of sacs. The answer to this question I believe we need not go far to seek; the third pair of the original five pairs of sacs has been converted into the so-called penes. These are more or less prominent papillæ, lateral to and near the bases of the third pair of parapodia. Each papilla is perforated by a ductus ejaculatorius, which widens proximally into a vesicula seminalis. The latter receives the mature spermatozoa from the vasa deferentia, and these in turn from the ramifying testicular follicles. Bizarre as the development of a male reproductive organ from a lateral line organ may appear at first sight, I am nevertheless unable to see any great difficulty in such a change of function. It is, in fact, easy to see how the bottom of an eversible sac might acquire an opening into the body-cavity under the pressure of a great accumulation of spermatozoa; the sac would then become reduced to a mere conduit."

A few years later von Stummer-Traunfels (16) investigated the anatomy of the curious endoparasitic form $M$. asterice Marenz., and showed that this species possesses a median sucker behind the last pair of parapodia; whilst describing. Wheeler's view of the homology of the penes as somewhat far-fetched, he considers this extra sucker to represent the missing fifth pair, and his researches on the innervation of this organ show that it must have been formed by the fusion of two originally separate suckers.

Since the publication of my preliminary note (3) on the suckers of $M$. costatum, Fedotov (6) has described a remarkable type of Myzostomid, an endoparasite of the brittle-star Gorgonocephalus eucnemis Müller et Troschel; in this form, named Protomyzostomum polynephris, five pairs of suckers are present, and these are not situated between the pairs of parapodia on the ventral side, but opposite to them and in a dorsal position. It is to be hoped that further investigation of the anatomy of this new genus may throw some light on the relations between suckers and parapodia in the Myzostomids ; meanwhile, the occurrence of six pairs of suckers in $M$. costatum merely complicates the problem. Granting the metameric nature of these organs, we must now consider that we are dealing with six segments instead of five, and it seems necessary to account for a missing sixth pair of parapodia*.

* Cf. also remarks under "Nervous System" on p. 95. 
The above description of $M$. costatum refers especially to fullgrown specimens measuring between $1 \frac{1}{2}$ and $4 \mathrm{~mm}$. in length. Young specimens under $1 \frac{1}{2} \mathrm{~mm}$. present a somewhat different appearance; the body is thinner, and the costr on the dorsal surface are less conspicuous than in the adult; though in some cases very faint they are never absent. The marginal region is more delicate and transparent than in the larger specimens, this being due to the absence of ova in the peripheral branches of the uterus ; 12-20 pairs of well-defined cirri are present, and between them can be seen smaller processes which are about to give rise to more of these organs. The last pairs of cirri show the same tendency towards enlargement as in the adults. The suckers are not very prominent, but the male papillæ are fully developed and are extremely conspicuous.

Before concluding my account of the external features of this species, I wish to call attention to the fact that quite a considerable number of specimens in Mr. Crossland's collection present abnormalities chiefly regarding the number of parapodia. In these specimens one or more parapodia are missing from one or both sides of the animal, and, although in some cases this may be due to injury and incomplete regeneration of parts of the body, in others the malformations must have been congenital. I have figured some of these abnormal specimens; the sketch (textfig. 18) on p. 91, shows an extreme case, that of an individual measuring $1 \cdot 25 \mathrm{~mm}$. in length, which possesses four parapodia on one side of the body and only two on the other; the rest of the animal seems normally developed, and the full number of suckers is present. In some cases reduction in the number of parapodia is accompanied by a similar reduction in the number of the suckers ( $c f$. text-fig. 17, p. 89 ).

\section{Alimentary Canal.}

As mentioned above, the mouth is situated on the ventral side close to the anterior extremity of the body; through it can be protruded a large and muscular pharynx provided at its distal end with small papillæ, as described by v. Graff; these are very inconspicuous in all the specimens before me, and, so far as I can ascertain, number four only.

The stomach is elongated, extending back as far as the level of the last pair of parapodial bases, and constricted laterally at the points where the intestinal branches arise, almost opposite the male genital papillæ.

There are only two intestinal trunks on each side arising close together from the stomach; these divide into from $7-9$ primary branches, which in their turn radiate outwards and give rise to numerous diverticula, which end blindly on the body-margin.

The rectum is separated from the stomach by a distinct valvelike constriction, and takes the form of a straight tube running back from the level of the last pair of parapodia to the cloaca, where it is joined by the oviduct. 
Surrounding the base of the pharynx and the extreme anterior end of the stomach is a thick ring of cells ( $c f$. Pl. VIII. fig. 3) resembling the "multipolar" cells described by Nansen ((15), p. 71) as occurring close to the circum-œsophageal nerve-ring in several species, and which he considered to be ganglionic cells forming a kind of sympathetic system. Similar cells were found by v. Stummer (16) in $M$. asterice, but this author showed that

Text-fig. 19.

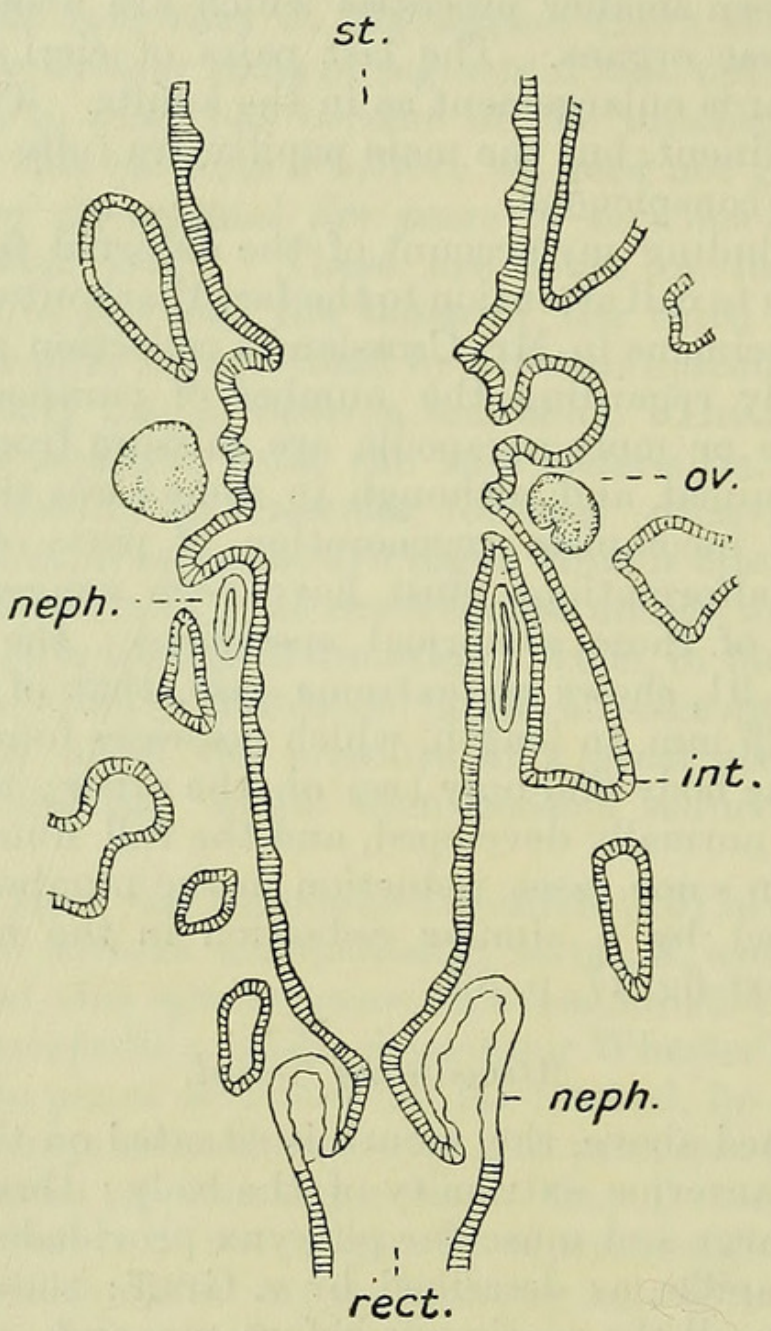

Myzostoma costatum.-Longitudinal horizontal section through part of the body to show the position of the ovaries and nephridia.

st. Stomach. rect. Rectum. int. Intestinal trunk. ov. Ovary. neph. Nephridium.

their minute structure differed considerably from that of ganglionic cells, and that the presence of secretion granules and capillary ducts indicated that they were of a glandular nature.

The cells surrounding the anterior end of the stomach of M. costatum very closely resemble those described by v. Stummer (cf. (16) p. 551, pl. xxxvii. figs. $5 \& 6$ ) ; in this species, however, they are more numerous and not so scattered; moreover, the capillary ducts are all directed towards the gastric epithelium. 
I think there can be little doubt but that v. Stummer was right in considering these cells to be unicellular glands. In $M$. costatum these glands may have a digestive function; they certainly form the only glandular tissue in connection with the alimentary canal in this species.

\section{Nervous System.}

The best and most complete account of the Myzostomid nervous system is that published by Nansen in 1885 (15); it was based on investigations made on several species, especially $M$. giganteum Nansen, M. graffi Nansen, and M. cirriferum Leuckart. In these forms, which can be regarded as quite typical, the nervous system consists of a feebly-developed circumpharyngeal ring communicating with a ventrally-situated unsegmented nerve-mass, from which eleven pairs of nerves arise. Of these nerves five on each side are large and supply the five parapodia, as well as the parts of the body-margin on both sides of them, whilst the other six are more slender and alternate with the larger nerves supplying the parts of the body between the parapodia.

Text-fig. 20.

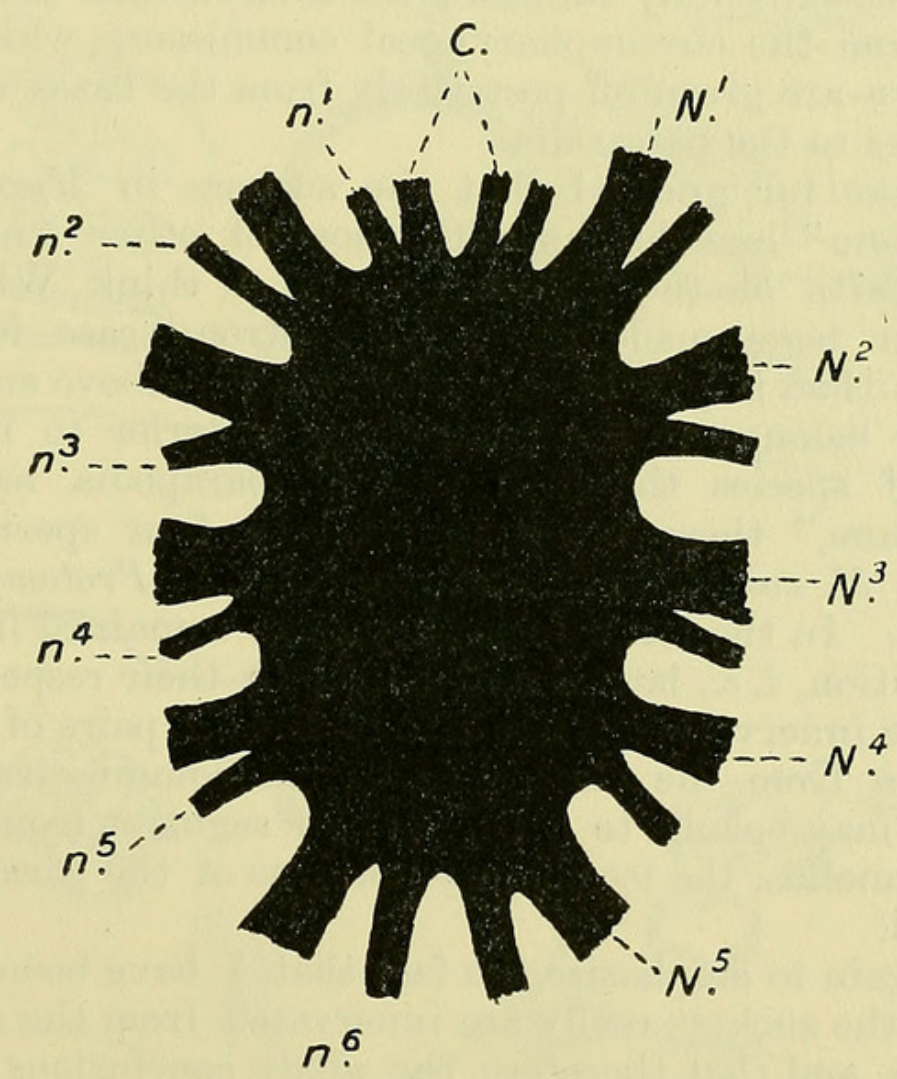

Diagram to show the origin of the paired nerves from the ventral nerve-mass in Myzostoma costctum.

$\mathrm{N}^{1}-\mathrm{N}^{5}$. The five pairs of large nerves. $n^{1}-n^{6}$. The six pairs of smaller nerves. C. Circumpharyngeal commissures.

Nansen did not state the nerve-supply of the "suckers," but v. Stummer (16) believes these organs to be innervated by branches 
of the small nerves, at least in the species which he examined, $M$. asterice Marenz.

I spent some time in attempting to reconstruct the nervous system of $M$. costatum, as I hoped that the distribution of the paired nerves might shed some light on the problem of the homologies of the additional suckers in this species ; the diagram (textfig. 20) on p. 95 gives, I think, a tolerably accurate idea of the nerves arising from the ventral nerve-mass.

It will be seen from the diagram that the nervous system of M. costatum is remarkably similar to that described by Nansen in other species, and especially to that of $M$. cirriferum; the number of nerves arising from the central mass is normal; there are eleven pairs, of which five are large and branch chiefly to the parapodia. I agree with v. Stummer in believing the suckers to be supplied by branches of the smaller intermediate nerves; the six pairs run almost straight out towards the six pairs of suckers, but I was unable to trace the finer branches actually into these organs.

It will be seen from my diagram that in $M$. costatum the origin of the six pairs of smaller nerves differs somewhat from that in the species described by Nansen; the first on each side seems to originate from the circumpharyngeal commissure, whilst the remaining five are given off posteriorly from the bases of the five larger nerves to the parapodia.

If we take for granted that the suckers in Myzostoma are "Seitenorgane" homologous with those of other Annelids and therefore parts of the parapodia-and I think Wheeler and v. Stummer have made out a very strong case for such a homology, - then it becomes obvious from the above account that each sucker belongs to the parapodium anterior to it. In the majority of species the fifth pair of parapodia has lost its "Seitenorgane," these being retained in four species only $M$. asteria, M. costatum, M. mobianum*, and Protomyzostomum polynephris. In the latter form they have remained in the more normal position, $i$.e., lateral and dorsal to their respective parapodia. The innervation of the first of the six pairs of suckers in $M$. costatum from the circumpharyngeal commissures suggests that these may belong to a peristomial segment from which, as in other Annelids, the locomotory portions of the parapodia have disappeared.

I wish again to emphasize the fact that I have been unable to prove that the suckers really are innervated from the six pairs of finer nerves, and that therefore the above conclusions are highly speculative. I think, however, that they afford a satisfactory explanation of the variation in the number of suckers in this group.

\section{Sexual Organs.}

Like nearly all well-investigated species of Myzostoma, $M$. cos tatum is hermaphrodite, and all the larger specimens in 
Text-fig. 21.
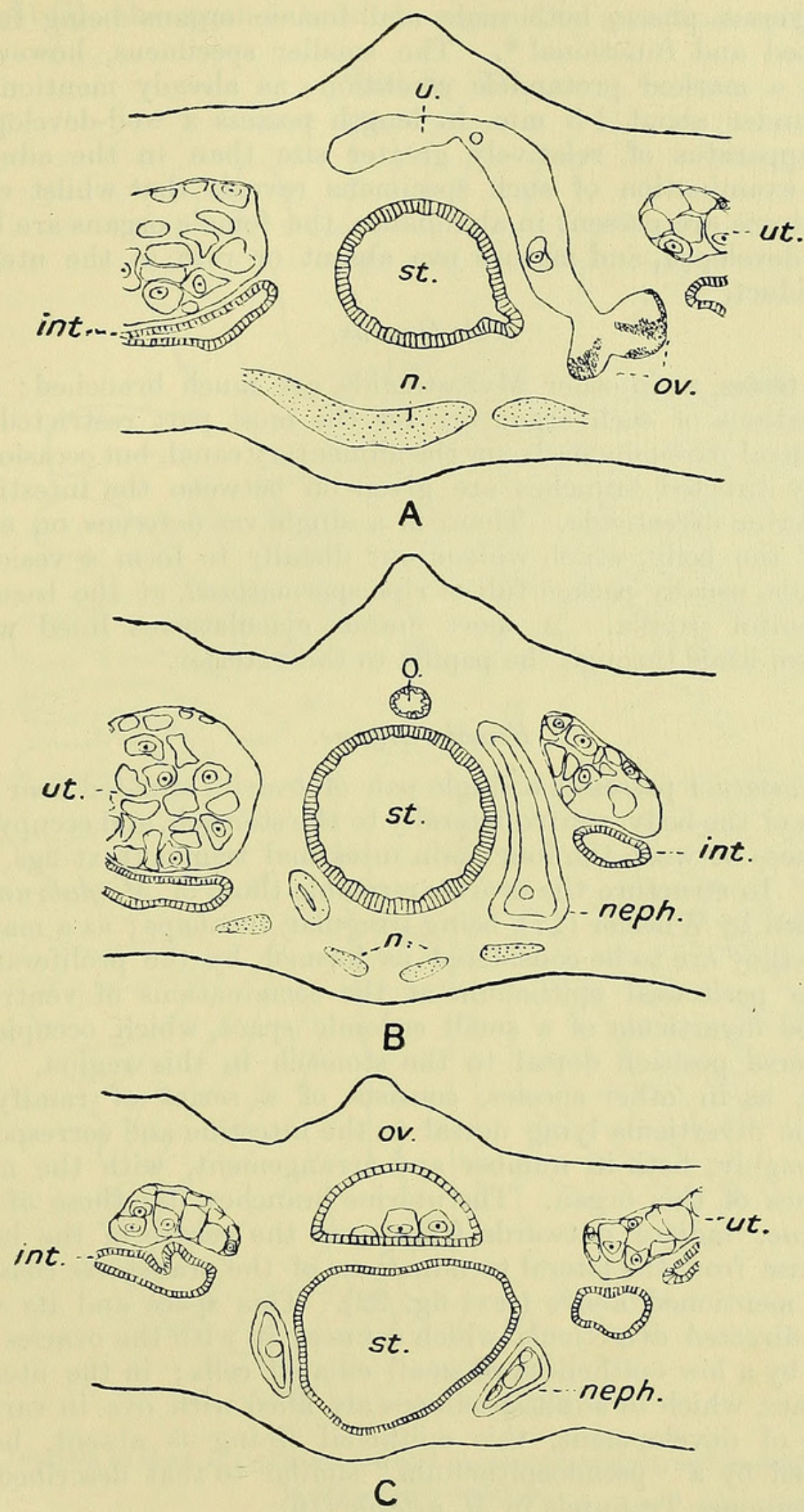

Myzostoma costatum.-Three transverse sections through the centre of the body : as in text-fig. 19, only the outlines of the various organs are shown and the testicular.follicles are omitted. The sections are slightly oblique, so that right and left halves of the figures show different regions.

st. Stomach. int. Intestinal branch. neph. Nephridium. n. Ventral nervous system. ov. Ovary. $o$. Anterior narrow end of the oviduct. $u$. Median division of the uterine cœlom. ut. Branch of the uterus.

Proc. Zool. Soc.-1913, No. VII. 
Mr. Crossland's collection are in what Wheeler (17) terms the androgynous phase, both male and female organs being fully developed and functional *. The smaller specimens, however, exhibit a marked protandric condition; as already mentioned, those under about $1.5 \mathrm{~mm}$. in length possess a well-developed male apparatus of relatively greater size than in the adults. Closer examination of such specimens reveals that whilst ripe spermatozoa are present in abundance, the female organs are but poorly developed, and mature ova absent or rare in the uterus and oviduct.

\section{Male Organs.}

The testes, as in other Myzostomids, are much branched; the ramifications of each organ are for the most part restricted to the ventral parenchyma below the alimentary canal, but occasional dorsally directed branches are given off between the intestinal and uterine diverticula. There is a single vas deferens on each side of the body, which widens out distally to form a vesicula seminalis, usually packed full of ripe spermatozoa, at the base of the genital papilla. A short ductus ejaculatorius lined with ectoderm leads through the papilla to the exterior.

\section{Female Organs.}

$M$. costatum possesses a single pair of ovaries situated near the middle of the body, ventro-laterally to the stomach, and occupying the spaces between the four main intestinal trunks (text-figs. 19, $21 \mathrm{~A})$. In structure the ovaries resemble those of $M$. glabrum as described by Wheeler (17), being irregular in shape; as a matter of fact they are to be considered as formed by the proliferation of the peritoneal epithelium at the terminations of ventrally directed diverticula of a small cœlomic space, which occupies a transverse position dorsal to the stomach in this region. The uterus, as in other species, consists of a series of ramifying cnelomic diverticula lying dorsal to the intestine and corresponding roughly, both in number and arrangement, with the main branches of this organ. The uterine branches, like those of the intestine, radiate outwards from near the centre of the borly, and arise from the lateral terminations of the transverse colomic space mentioned above (text-fig. 22). This space and its ventrally directed diverticula which connect it with the ovaries are lined by a low epithelium of small ciliated cells; in the uterine branches, which in adult specimens are filled with ova in various stages of development, this epithelial lining is absent, being replaced by a "pseudoepithelium" similar to that described by von Stummer-Traunfels in $M$. asterice (16).

The oviduct is sharply marked off from the uterus; it lies dorsal to the stomach and rectum in the middle line, and has the form of a straight wide tube, narrowing somewhat posteriorly, and

$$
\text { * Cf. also Coventry (5). }
$$


much dorsiventrally compressed along its whole length (textfig. $21 \mathrm{C}$ ); the organ is lined throughout by a distinct epithelium

Text-fig. 22.

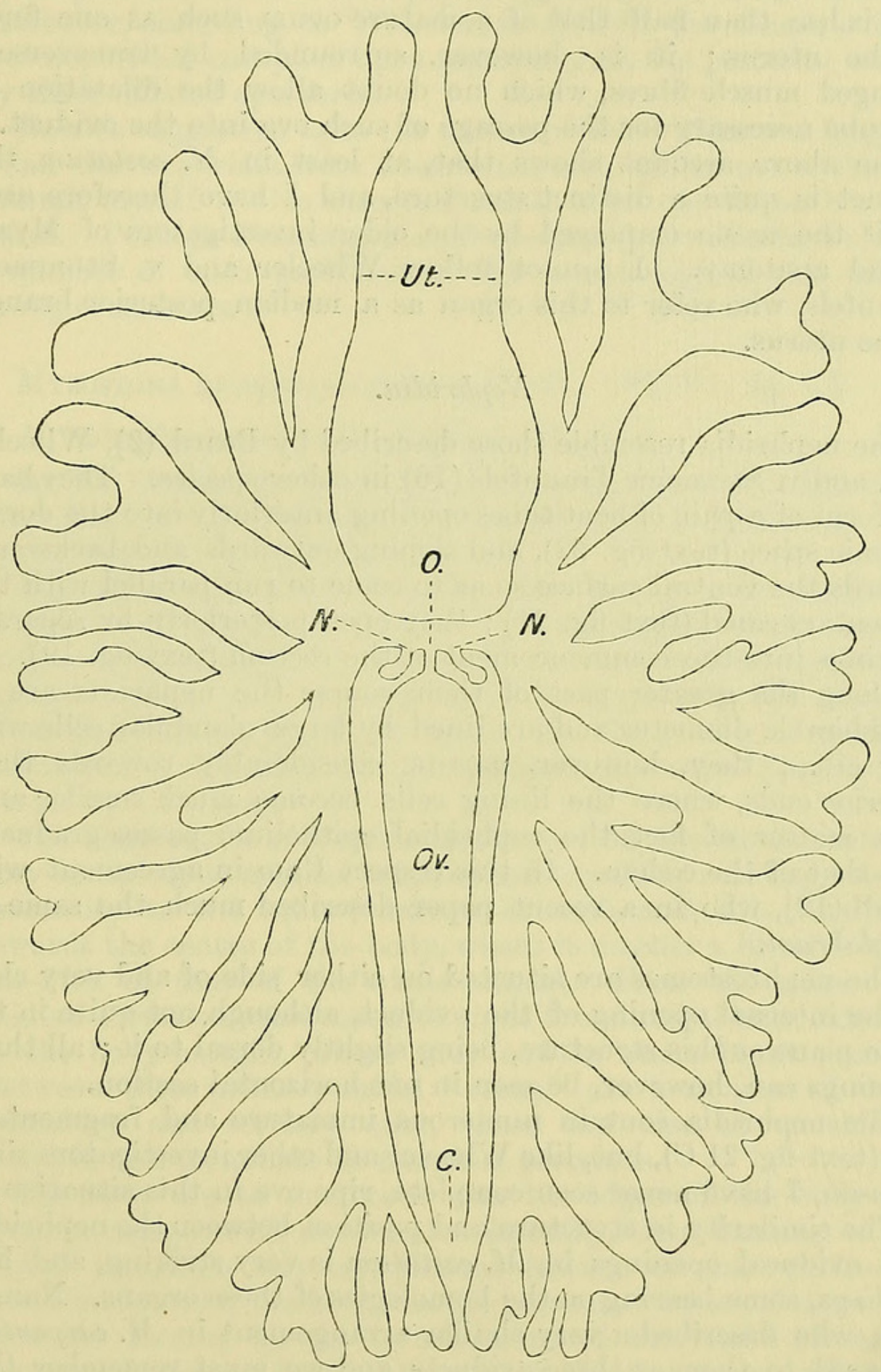

Diagram to show the relations between the uterus, oviduct, and nephridia in Myzostoma costatum.

$U i$. Uterus. Ov. Oviduct. $O$. Opening of oviduct into the uterine cœlom. $N$. Internal openings of the nephridia. C. Position of the cloaca.

of comparatively large ciliated cells. Anteriorly the oviduct communicates with the central coelomic space by means of a 
short, narrow duct (text-figs. $21 \mathrm{~B}$ and 22, and Pl. VIII. figs. 2 and 4), also lined by a ciliated epithelium; the latter, however, consists of very small cells with long cilia, and seems continuous with the epithelium lining the colom. The diameter of this tube is less than half that of a mature ovum such as one finds in the uterus ; it is, however, surrounded by transversely arranged muscle-fibres, which no doubt allow the dilatation of the tube necessary for the passage of such ova into the oviduct.

The above account shows that, at least in $M$. costatum, the oviduct is quite a distinct structure, and I have therefore used for it the name employed by the older investigators of Myzostomid anatomy. I cannot follow Wheeler and v. StummerTraunfels, who refer to this organ as a median posterior branch of the uterus.

\section{Nephridia.}

The nephridia resemble those described by Beard (2), Wheeler (17), and v. Stummer-Traunfels (16) in other species. They have the form of a pair of bent tubes opening anteriorly into the dorsal cœlomic space (text-fig. 22), and sloping outwards and backwards towards the ventral surface so as to come to run parallel with the alimentary canal (text-fig. 21) ; they open posteriorly by separate openings into the commencement of the rectum (text-fig. 19).

Along the greater part of their course the nephridia are of considerable diameter and are lined by large glandular cells with long cilia; they, however, narrow considerably towards their anterior ends, where the lining cells become much smaller and, as a matter of fact, the nephridial epithelium passes gradually into that of the colom. In this respect I am in agreement with Maidl (12), who in a recent paper described much the same in M. glabrum.

The nephrostomes are situated on either side of and very close to the internal opening of the oviduct, although not quite in the same plane as this structure, being slightly dorsal to it; all three openings can, however, be seen in one horizontal section.

The nephridia contain numerous immature and fragmentary ova (text-fig. $21 \mathrm{C}$ ), but, like Wheeler and other investigators since Nansen, I have never seen complete, ripe ova in this situation.

The similarity in structure and position between the nephridial and oviducal openings in $M$. costatum is very striking, and has, perhaps, some bearing on the homologies of these organs. Nansen (15), who described a very similar arrangement in $M$. carpenteri, referred to them as three oviducts, and we must remember that before his discovery of the "lateral oviducts" Beard (1) had suggested that "the oviduct opening into the cloaca may perhaps originally have been formed from two segmental organs, for the cloaca is an epidermic invagination, and if it were obliterated the oviduct would open on the median line." That partial fusion of a pair of segmental organs can take place has been shown by Wheeler (17), who described the nephridia of $\boldsymbol{M}$. glabrum as 
possessing a single nephrostome as well as an unpaired end-piece opening into the rectum; a similar condition is to be found in M. cryptopodium, where, however, the median end-piece opens directly to the exterior on a papilla just under the cloacal orifice. Moreover, according to Wheeler, in M. belli the cloaca, oviduct, and nephridial end-piece open separately on the posterior surface by three ciliated apertures.

Beard's suggestion as to the nature of the oviduct was forgotten when the nephridia were discovered, and, whilst not wishing to commit myself to this theory, I recall it as one to be borne in mind. Perhaps Protomyzostomum polynephris will afford clues to a number of such problems in the morphology of this difficult group of animals.

\section{Myzostoma rubrofasciatum v. Graff. (Pl. VI. fig. 1.)}

M. rubrofasciatum v. Graff (8), p. 33, pl, ii.

In Mr. Crossland's collection are two specimens of a Myzostoma from Forculch Barrier Island, obtained from a Comatulid which unfortunately cannot now be traced.

The animals are of an oval shape, but, owing to the contraction of the bodies being accompanied by a curling-up of the anterior and posterior ends ( $c f$. Pl. VI. fig. 1$)$, it is impossible to give exact measurements. One specimen is a little larger than the other, and must have had a length of about $2 \frac{1}{2} \mathrm{~mm}$., with a maximum breadth of $2 \mathrm{~mm}$; the smaller specimen measures approximately $\mathrm{mm}$. by $1.75 \mathrm{~mm}$.

The body is of considerable thickness ; on the dorsal side is a very conspicuous median longitudinal elevation running from one extremity to the other; narrow at each end, it is very broad towards the centre of the body, where it reaches a breadth almost one-fifth of that of the whole animal. From the sides of the median elevation arise seven to eight broad radial ones extending to the body-margin, where they end in short blunt processes. Between these primary radial "costr" are a number of shorter secondary and tertiary ones, these are also of considerable breadth, and terminate in marginal processes.

The costr are so numerous near the edges of the body as to come in contact with one another laterally, thus forming a thick ribbed margin, a very conspicuous feature of this species. As mentioned above, the body-margin presents a series of short blunt processes formed by the terminations of the radial elevations; there are between 25 and 30 pairs of these processes, which are very irregular in size and shape. In both specimens, however, the last pair and, to a slightly less degree, the penultimate and antepenultimate pairs, are considerably enlarged and thickened.

The coloration of the dorsal surface in the preserved specimens is peculiar and very characteristic; the median elevation and the costre are of a yellowish colour ; the rest of the dorsal surface is brownish, except where a pair of narrow light-coloured streaks 
run longitudinally down the body, each about halfway between the middle line and the margin. Although expressed somewhat differently, it will be seen that this colour-pattern is practically identical with that described by v. Graff (8) in M.rubrofasciatum, a Myzostomid obtained from an unidentified Crinoid in the Red Sea at Tur, near Sinai. I think there can be no doubt that Mr. Crossland's two specimens must be referred to the same species.

v. Graff's description was based on a single individual, which was more brightly coloured than those I am describing, moreover, at first sight it seems to differ considerably in shape from those specimens. This difference is, in my opinion, due entirely to the mode of contraction, the body in v. Graff's specimen having the sides bent ventrally so as to give it the form of a boat, the median elevation representing the keel.

Owing to the state of contraction of his only specimen, v. Graff was not able to describe the ventral surface at any length. In the individuals collected by Mr. Crossland the ventral surface is yellowish in colour, and the central muscular mass prominent. The five pairs of parapodia are well developed and, as in $M$. costatum, without division into proximal and distal regions; they arise approximately halfway between the centre of the body and the margin.

There are four pairs of suckers of relatively large size with radially folded walls. They are in the normal position between the parapodia, and are situated close to the periphery.

Both mouth and cloaca are subterminal.

The male papillæ are not conspicuous; they have the form of short conical processes in the usual position lateral to the third pair of parapodial bases.

I did not feel justified in cutting sections as I had only two specimens of this species at my disposal, and neither seemed likely to yield good results. One individual was cleared in cerlar wood oil, but owing to the thickness of the body revealed practically nothing of the internal organisation.

Mrzostoma crosslandi, sp. n. (Pl. VI. figs. 2, 3 ; Pl. VII., \& Pl. VIII. fig. 1.)

From various localities in the Red Sea Mr. Crossland obtained four specimens of a large elongated Myzostomid (Pl. VI. figs. 2, 3) which is evidently closely related to $M$. nansen $i$ v. Graff; but sufficiently distinct, in my opinion, to justify the creation of a new species to receive it. This form, which I name $M$. crosslandi, is in certain respects intermediate between $M$. nanseni and M. folium v. Graff.

Of the four individuals one was found at Ul Shubuk on Antedon suvignyi, another in Suez Bay at a depth of 10 fathoms on Antedon serripinna, whilst the other two were obtained from a Comatulid which I have been unable to trace.

As mentioned above, this Myzostomid is of comparatively large 
size, the lengths of the specimens measuring $8.5,8,8$, and $5 \mathrm{~mm}$. respectively.

The bodies have a maximum thickness of about $1 \mathrm{~mm}$.; owing to the fact that all four specimens were contracted with the sides incurved ventrally, it is impossible to give exact measurements of the breadths, these, however, I estimate as varying between 3 and $3.5 \mathrm{~mm}$, in the different individuals.

The body-disc is rounded off anteriorly and posteriorly; it does not terminate in a point, as in $M$. folium. The thick body thins out gradually towards the edges, and has a narrow translucent margin which is finely notched, giving rise to a number of inconspicuous marginal processes ending in fine points.

The dorsal surface is smooth; a median longitudinal elevation is noticeable in three specimens, and is conspicuous only posteriorly in the region of the oviduct; on either side are feeble elevations corresponding in position to the parapodial insertions.

Mouth and cloaca are to be seen on the ventral side, situated on small papillæ and both close to the extremities, in this respect differing from $M$, nanseni, where the cloacal papilla lies at the commencement of the last quarter of the body, A narrow median ridge projects on the ventral surface, and marks the position of the stomach and rectum.

The parapodia are well developed and arranged in two almost parallel rows; the first pair lies close behind the mouth, but the insertions of the last pair are, as in $M$. nanseni and $M$. folium, at a considerable distance from the posterior termination of the body, this distance varying in the different specimens between a quarter and a third of the total length of the animal. Each parapodium is strong and, as in the two species just mentioned, consists of a broad muscular region, situated proximally, and of a narrower distal region provided with a conspicuous longitudinal groove on its ventral face.

The male papiliæe are inconspicuous and have the form of short conical processes in the usual position (text-fig. 23, p, 104). At first I thought that suckers were absent, and I could detect none under a low magnification; the use of a higher power of the microscope, however, revealed up to four pairs of these structures between the parapodia and close to the body-margin (text-fig, 23). They are much smaller than those described by v. Graff (9) in $M$. nanseni, and are, I think, in a vestigial condition.

The colour-pattern of $M$. crosslandi is quite characteristic; the dorsal surface in the spirit specimens varies from a greenish grey to a brown colour, with seven or more pairs of very narrow lighter. bands running transversely across the body at regular intervals. I have no information as to the colour of fresh individuals.

Among a number of young specimens of $M$. costatum from Ul Shubuk I found two small individuals which I take to be young stages of $M$. crosslandi. They measure $1.25 \times 1 \mathrm{~mm}$. and $1 \times .75 \mathrm{~mm}$. respectively. The last pair of parapodia lies much closer to the posterior extremity of the body than in the specimens 
just described, but, except for this and the proportions of length to breadth, they resemble the adults in every respect. Neither cirri nor suckers are better developed than in the latter, and, as a matter of fact, I could not trace any suckers at all in one of these young specimens.

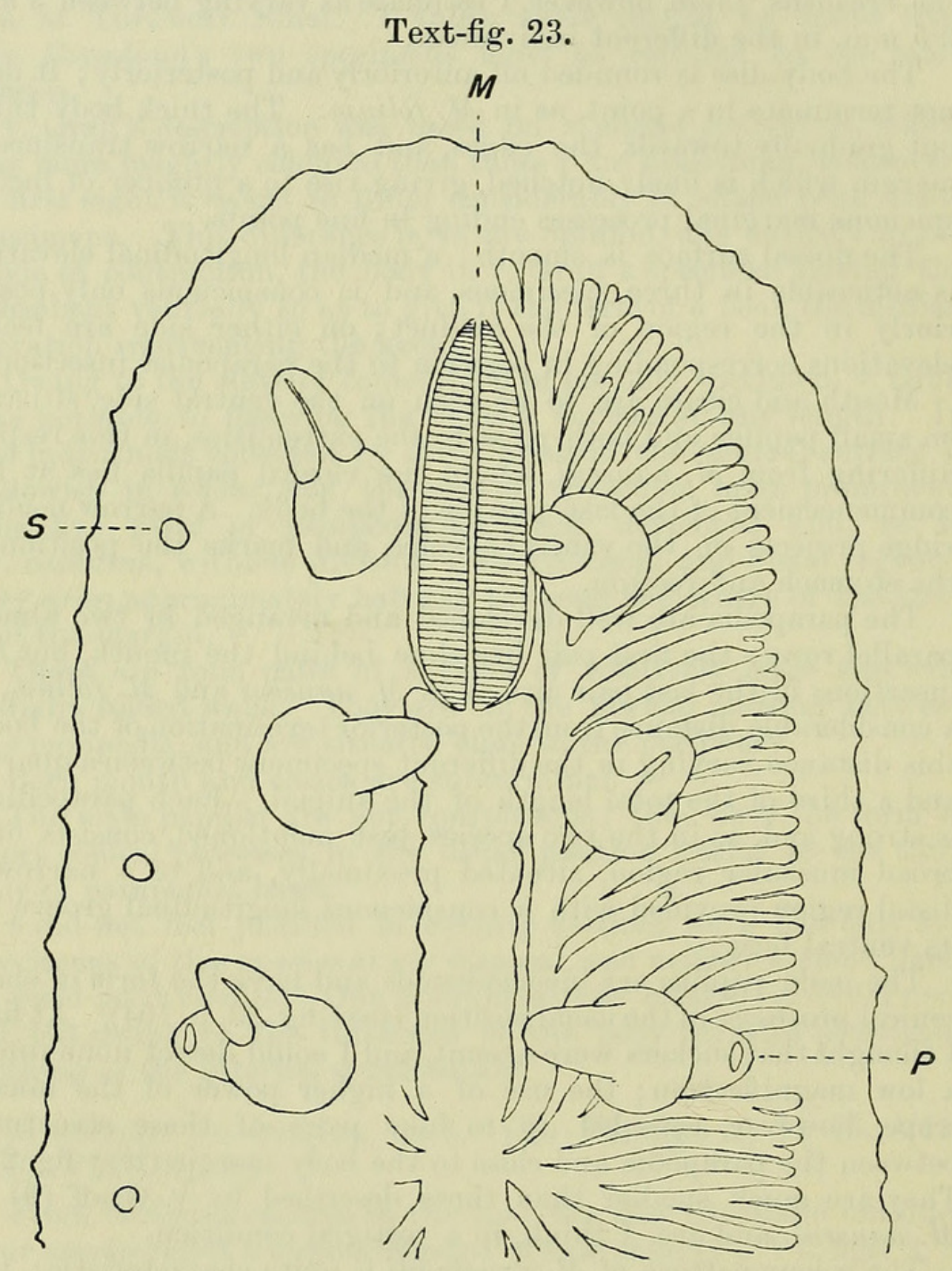

Myzostoma crosslandi, sp. n.-Anterior part of the body; sketch made from a specimen cleared in cedarwood oil.

M. Mouth. P. Male papilla. S. Vestigial sucker.

No complete account of the anatomy of any of the large elongated Myzostomids has yet been published. I therefore used one of the larger specimens of $M$. crosslandi for the preparation of sections; when merely cleared in cedarwood oil they showed little more than just the peripheral parts of the alimentary canal. 
A series of transverse sections was obtained, and they show a very characteristic feature of this species, namely, the great development of the "Hautmuskelschlauch," the musclesheath below the skin (Pl. VII., \& Pl. VIII. fig. 1); it is best developed on the dorsal side of the animal, where it is separated from the outer epithelium by a cutis-like layer of connective tissue. This cutis is absent from the ventral surface, and here the musclesheath can be seen to consist of distinct outer and inner layers of transverse and longitudinal fibres respectively.

\section{Alimentary Canal.}

The mouth leads into a muscular elongated pharynx, which, when retracted, extends back in the body almost as far as the level of the second pair of parapodia. The pharynx was in this condition in all four specimens, and I was therefore unable to make out whether terminal papillæ occur. There is no distinct œsophagus, the pharynx leading directly into the stomach; this part of the alimentary canal is comparatively narrow and of considerable length; slightly sacculated anteriorly, it gives off on each side three intestinal trunks which arise close together at a point just posterior to the level of the third pair of parapodial insertions. The central of these three trunks branehes profusely in the normal manner, but supplies only a small area of the body with intestinal cæca; the anterior and posterior trunks, however, continue in a straight course forwards and backwards respectively to the two extremities and, keeping close to the middle line, supply the rest of the body with numerous almost parallel branches given off from their external sides only. This peculiar and very characteristic arrangement of the intestinal branches (text-fig. 23) recalls that described by v. Graff in $M$. elongatum (7); it seems probable that it will be found to occur in all the elongated species.

The rectum commences a short distance behind the last pair of parapodia and runs backwards as a straight narrow tube, which opens on a small but conspicuous papilla (Pl. VIII. fig. 1) close to the posterior margin of the body.

I could find no trace of salivary glands in connection with the alimentary canal, and the peculiar glandular tissue described as surrounding the anterior part of the stomach in $M$. costatum is very poorly developed in this species.

\section{Reproductive Organs.}

The single specimen sectioned proved to be in an androgynous condition, and both sets of organs seemed equally developed.

\section{Male Organs.}

The testes (Pl. VII.) are embedded in the parenchyma, chiefly ventral to the alimentary canal, but a certain number of follicles, as in $M$. costatum, extend upwards between the intestinal branches 
and come to occupy a dorsal position between or above the uterine cæca.

The testicular follicles are in some cases enclosed in small cavities which, in agreement with most recent workers, I consider to be cœlomic ; these cavities are in places considerably enlarged, and are then filled with large masses of mature spermatozoa (Pl. VII. fig. 5) ; their size equals or exceeds that of the uterine spaces, which they resemble except for the nature of their contents. Some of these cavities seem to have lost their communications with the rest of the male organs, and $I$ am at a loss to explain how the spermatozoa within them can make their way to the exterior.

Wheeler seems to have observed a somewhat similar condition of the male organs in his species $M$. circinatum, but in this form vesiculæ seminales and "penes" appear to be absent; in $M$. crosslandi the majority of the testicular follicles communicate with the vasa deferentia, and through these with seminal vesicles which open on to the short male papillæ.

\section{Female Organs.}

The female organs of $M$. crosslandi are very similar to those just described by me in $M$, costatum. The single pair of hollow ovaries (Pl. VII, fig. 1) lies ventro-laterally to the stomach just behind the point of origin of the first pair of intestinal trunks. The cavities of the ovaries communicate with a pair of narrow colomic tracts which run upwards along the sides of the stomach to join the small median cœlomic space from which the uterine branches are given off. The latter are numerous and relatively very slender; they follow the main ramifications of the intestine.

As in $M$. costatum, the oviduct communicates with the median uterine cœlom by means of a narrow ciliated duct, which in this species is rather long. The oviduct itself is very slender and much compressed so as to appear crescentic in transverse sections; it decreases in width considerably in the region of the rectum and opens on the cloacal papilla by a very narrow terminal tube.

\section{Nephridia.}

The nephridia (Pl. VII. figs, 2-5) occupy very much the same position as in $M$. costatum, and, as in that species, open posteriorly into the sides of the rectum close behind the commencement of that organ. Unlike $M$. costatum, the anterior ends of the nephridia do not communicate directly with the median uterine cœlom, but open separately into the narrow anterior end of the oviduct, so that the three tubes which afford communication between the colom and the exterior possess but a single internal opening.

The anterior terminal part of each nephridium has the form of a transversely set narrow tube lined with long cilia; this widens out laterally when the organ follows a rather sinuous course, backwards and downwards, and comes to form a broader tube 
lying ventral to the stomach. The nephridia run side by side ventral to the stomach for a short distance, but in the posterior region of that organ slope upwards again, finally lying lateral to the rectum just before opening into it.

\section{Nervous System.}

I was able to make out very little of the nervous system of this species, as the peripheral nerves were only very poorly stained in my sections. The central nerve-mass was, however, distinct and occupied the same position as in other species, that is to say the centre of the body, in the region between the second and fourth pairs of parapodia.

This typical concentration of the central nervous system is a point of interest, since it shows that the elongated form of $M$. crosslandi is probably not a primitive character; the arrangement of the intestinal branches and other organs also indicates that this species is derived from some form possessing a more radial symmetrý.

This is probably also true of allied species, such as $M$. nanseni and $M$. folium.

\section{List of References.}

1. Beard, J.- " On the Life-History and Development of the Genus Myzostoma (F. S. Leuckart)." Mitth. Zool. Stat. Neapel, Bd. v. 1884, p. 544.

2. - "The Nature of the Hermaphroditism of Myzostoma." Zool. Anz. Bd. xvii. 1894, p. 399.

3. Boulenger, C. L.- "The 'Suckers' of the Myzostomidæ." Zool. Anz. Bd. xxxvii. 1911, p. 346.

4. Clark, H. L.- "A new Host for Myzostomes." Zool. Anz. Bd. xxv. 1902, p. 670.

5. Coventry, A. F.- "The Application of Mr. G. W. Smith's Theory of Dwarf Males to Myzostoma." Ann. Mag. Nat. Hist. ser. 8, vol, v. 1910 , p. 378.

6. Fedotov, D. - "Protomyzostomum polynephris, eine nene Myzostomidenart." Zool. Anz. Bd. xxxix. 1912, p. 649.

7. GrafF, L. v.-."Das Genus Myzostoma (F. S. Leuckart)." Leipzig, 1877 .

8. - "Report on the Myzostomida collected ciuring the Voyage of H.M.S. 'Challenger' during the Years 187376." Rep. 'Challenger' Exped. vol, x. Pt. 27, 1884.

9. lenger' Exped. vol. xx. Pt. 61, 1887.

10. Leuckart, F. S.- "Bericht über die achte Versammlung deutscher Naturforscher und Aerzte zu Heidelberg im September 1829.” Oken's Isis, 1830, Heft v. p. 612.

11. - "Zoologische Bruchstiicke. III. Helminthologische Beiträge." Programm zur Eröffnung der Wintervorles ungen in Freiburg i. B. 1842, p. 5. 
12. Maidu, F._-"Ueber die Cœlomverhältnisse von Myzostoma." Verh. zool.-bot. Ges. Wien, Bd. lx. 1910, p. 200.

13. MuClendon, J. F.- "The Myzostomes of the 'Albatross' Expedition to Japan." Bull. Amer. Mus. Nat. Hist. vol. xxii. 1906 , p. 119.

14. - "New Marine Worms of the Genus Myzostoma." Smithson. Inst. U.S. Nation. Mus. Proc. vol. xxxii. 1907, p. 63.

15. Nansen, F. - "Bidrag til Myzostomernes Anatomi og Histologi." Bergen, 1885.

16. Stummer-Traunfels, R. v.—“Beiträge zur Anatomie und Histologie der Myzostomen. I. Myzostoma asterice Marenz." Zeitschr. f. wiss. Zool. Bd. Ixxv. Heft 4, 1903, p. 49 .

17. Wheeler, W. M.- "The Sexual Phases of Myzostoma." Mitth. Zool. Stat. Neapel, Bd. xii. Heft 2, 1896, p. 227.

\section{EXPLANATION OF THE PLATES.}

\section{Plate V.}

Figs, 1-6. Myzostoma costatum F. S. Leuckart.-Series of specimens illustrating the variation in the shape of the body and the development of the costæ. The individuals shown in figs. 2 and 3 possess an abnormal number of parapodia ( $c f$. p. 93). In all the figures $a$ represents the dorsal, $b$ the ventral aspect of the animal. $\times 12$.

\section{Plate Vi.}

Fig. 1. Myzostoma rubrofasciatum v. Graff.-Dorsal view. $\times 18$.

Figs. 2-3. Myzostoma crosslandi, sp. n.-Two specimens, dorsal and ventral aspects. $\times 12$.

\section{Plate ViI.}

Figs. 1-5. Myzostoma crosslandi, sp. n,-Transverse sections to show the anatomy. c.n. Central nerve-mass. int. Branch of intestine. $m$. Muscular sheath. $n$. Nephridıum, o. Ovary. ov. Oviduct. $r$. Rectum. $s p$. Mass of spermatozoa occupying cœlomic space. st. Stomach. te. Testis. ut. Branch of the uterus.

Fig. 1. Section passing through the ovaries.

Figs. 2-4. Sections passing through the anterior portion of the oviduct and showing the position of the nephridia.

Fig. 5. Section passing through the posterior parts of the stomach and oviduct.

\section{Plate VIII.}

Fig. 1. Myzostoma crosslandi, sp. n.-Photograph of a transverse section through the posterior region of the body, passing through the cloacal papilla (cl.p.). Lettering as in Plate ViI.

Fig. 2. Myzostoma costatum F.S. L.-Photograph of a longitudinal section showing the principal organs. ph. Pharynx.

Fig. 3. Myzostoma costatum F. S. L. Photograph of a transverse section passing through the anterior extremity of the stomach and showing the ring of glandular tissue $(g l$.$) developed round the alimentary canal in this$ region.

Fig. 4. Myzostoma costatum F. S. L.-Part of the same section as fig. 2, under a higher magnification. $g l$. Glandular tissue. 


\section{$2 \mathrm{BHL}$ Biodiversity Heritage Library}

Boulenger, Charles L. 1913. "Report on the Myzostomida collected by Mr. Cyril Crossland in the Red Sea in 1905." Proceedings of the Zoological Society of London 1913, 85-108.

View This Item Online: $\underline{\text { https://www.biodiversitylibrary.org/item/99850 }}$

Permalink: https://www.biodiversitylibrary.org/partpdf/70353

\section{Holding Institution}

Smithsonian Libraries

\section{Sponsored by}

Biodiversity Heritage Library

\section{Copyright \& Reuse}

Copyright Status: Public domain. The BHL considers that this work is no longer under copyright protection.

This document was created from content at the Biodiversity Heritage Library, the world's largest open access digital library for biodiversity literature and archives. Visit BHL at https://www.biodiversitylibrary.org. 